\title{
Sistem Pendukung Keputusan Pemberian Kredit Rumah Sejahtera Pada Nasabah Bank Pembangunan Daerah Kalimantan Timur dengan Metode TOPSIS
}

\author{
Agus Jumadi ${ }^{a^{*}}$, Zainal Arifin ${ }^{\mathrm{b}}$, Dyna Marisa Khairina ${ }^{\mathrm{c}}$ \\ ${ }^{a, b, c}$ Program Studi Ilmu Komputer Fakultas Matematika dan Ilmu Pengetahuan Alam \\ Universitas Mulawarman Samarinda
}

Naskah Diterima : 14 Oktober 2014; Diterima Publikasi : 12 Nopember 2014

\begin{abstract}
One of the most basic of human needs is the house as a place to live and settle. To be able to have a house requires a considerable cost. Therefore, we need a party as an intermediary to ease of payment to purchase of the house. The intermediary in this case is Bank. In this study, the Regional Development Bank (BPD) in East Kalimantan into a bank that was taken as a reference to obtain a loan writers Mortgage Prosperity. During this time, the decision making is done by the analysis of credit (account officer), always has a lot of obstacles, such as the decision-making process is not effective (use of longer periods of time, effort and money is wasted), human error and the possibility of collusion between customers and officers of the Bank. Web-based system is built so that users can easily access the system anytime and anywhere. Provision of decision support systems Prosperous Home Lending (KRS) for customers of Regional Development Bank (BPD) in East Kalimantan with Technique For Others Reference by Similarity to Ideal Solution (TOPSIS) methods as a determinant of final calculation from value of available alternatives. TOPSIS is not only consider the closest distance to the ideal solution, but also takes into account the distance to the farthest negative ideal solution to determine the selected alternative. Result from this study is an application decision support facilitate decision-making to facilitate decision-making releated to the problem of determining the recipient of a prosperous home loans in BPD Kaltim, so it can provide decision analysts credit home loans prosperous and appropriately based systems.
\end{abstract}

Keywords : Decision Support System; Prosperous Home Lending Development; Topsis Method

\begin{abstract}
Abstrak
Salah satu kebutuhan manusia yang paling pokok adalah rumah sebagai tempat tinggal dan menetap. Untuk bisa memiliki rumah memerlukan biaya yang cukup besar. Oleh karena itu, dibutuhkan suatu pihak sebagai perantara untuk meringankan beban pembayaran pembelian rumah tersebut. Pihak perantara dalam hal ini adalah Bank. Dalam penelitian ini, Bank Pembangunan Daerah (BPD) Kalimantan Timur menjadi Bank yang diambil penulis sebagai referensi memperoleh pinjaman Kredit Rumah Sejahtera. Selama ini, pengambilan keputusan yang dilakukan oleh analisis kredit (account officer), selalu memiliki banyak kendala, seperti proses pengambilan keputusan yang tidak efektif (penggunaan waktu yang cukup lama, tenaga dan biaya yang terbuang), human error, dan adanya kemungkinan kolusi antara nasabah dan petugas Bank. Sistem ini dibuat berbasis web sehingga pengguna dengan mudah dapat mengakses sistem ini kapanpun dan dimanapun. Penyediaan sistem pendukung keputusan pemberian kredit rumah sejahtera (KRS) pada nasabah Bank Pembangunan Daerah (BPD) Kalimantan Timur dengan metode Technique For Others Reference by Similarity to Ideal Solution (TOPSIS) sebagai penentu hasil akhir perhitungan nilai alternatif yang tersedia. Metode TOPSIS tidak hanya memperhitungkan nilai terdekat dengan solusi ideal positif, namun juga memperhitungkan nilai terjauh dengan solusi ideal negatif untuk menentukan alternatif terpilih. Hasil dari penelitian ini adalah sebuah aplikasi sistem pendukung keputusan yang bermanfaat untuk memudahkan pengambilan keputusan yang terkait dengan masalah menentukan penerima kredit rumah sejahtera pada nasabah BPD Kaltim, sehingga analis kredit dapat memberikan keputusan pinjaman kredit rumah sejahtera secara tepat dan sesuai berdasarkan sistem.
\end{abstract}

Kata Kunci: Sistem Pendukung Keputusan; Kredit Rumah Sejahtera; Metode Topsis

\section{Pendahuluan}

Rumah merupakan kebutuhan primer bagi manusia sebagai tempat tinggal dan menetap. Untuk bisa memiliki rumah memerlukan biaya yang cukup besar. Beberapa orang dari kalangan tertentu

*) Penulis korespondensi: agoesjuma08@gmail.com mungkin mampu untuk membeli rumah secara tunai pada developer real estate atau pihak tertentu yang hendak menjual rumah. Namun, tidak sedikit pula orang yang tidak mampu menyediakan biaya yang besar tersebut untuk membeli rumah yang layak untuk dihuni (Nasution, 2009). 
Oleh karena itu, dibutuhkan suatu pihak sebagai perantara untuk meringankan beban pembayaran pembelian rumah tersebut. Pihak perantara dalam hal ini adalah Bank. Dalam penelitian ini, Bank Pembangunan Daerah (BPD) Kalimantan Timur menjadi Bank yang diambil penulis sebagai referensi memperoleh pinjaman Kredit Rumah Sejahtera.

Selain sebagai badan usaha yang menghimpun dana dari masyarakat dalam bentuk simpanan. Bank juga menyalurkan kepada masyarakat dalam bentuk kredit. Kredit merupakan sumber pendapatan dan keuntungan Bank, tetapi juga kegiatan penanaman dana yang menjadikan penyebab utama Bank menghadapi masalah. Kegiatan usaha Bank yang berhasil mengelola kreditnya maka berkembang, sedangkan usaha Bank yang tidak dapat mengelola kreditnya maka mundur. Suatu kredit yang diberikan dikatakan bermutu apabila nasabah melunasi kredit tepat waktu. Namun, jika Bank tidak dapat memperoleh kembali cicilan pokok dari pinjaman yang diberikan maka muncul resiko kredit. Hal tersebut terjadi karena pengambilan keputusan yang dilakukan oleh staf penganalisis kredit (account officer), selalu memiliki banyak kendala, seperti proses pengambilan keputusan yang tidak efektif (penggunaan waktu yang cukup lama, tenaga dan biaya yang terbuang), human error dan adanya kemungkinan kolusi antara calon nasabah dan petugas Bank. Sehubungan dengan hal tersebut, maka diperlukan aplikasi Sistem Pendukung Keputusan Pemberian Kredit Rumah Sejahtera (KRS) Pada Nasabah Bank Pembangunan Daerah (BPD) Kalimantan Timur dengan Metode Technique For Order Preference By Similitary To Ideal Solution (TOPSIS). Dalam hal ini dapat memberikan rekomendasi pada Bank untuk memilih nasabah yang layak menerima pemberian kredit rumah sejahtera sesuai dengan kriteria yang ditentukan Bank.

TOPSIS merupakan suatu bentuk metode pendukung keputusan yang didasarkan pada konsep bahwa alternatif yang terbaik tidak hanyak memiliki jarak terpendek dari solusi ideal positif tetapi juga memiliki jarak terpanjang dari solusi ideal negatif. Konsep ini banyak digunakan untuk menyelesaikan masalah keputusan secara praktis. Konsepnya sederhana dan mudah dipahami, komputasinya efisien dan memiliki kemampuan untuk mengukur kinerja relatif dari alternatif-alternatif keputusan dalam bentuk matematis yang sederhana.

\section{Kerangka Teori}

\subsection{Sistem Pendukung Keputusan}

Sistem Pendukung Keputusan secara umum didefinisikan sebagai sebuah sistem yang mampu memberikan kemampuan baik kemampuan pemecahan masalah maupun kemampuan pemgkomunikasian untuk masalah semi-terstruktur. Secara khusus, SPK didefinisikan sebagai sebuah sistem yang mendukung kerja seorang manajer maupun sekelompok manajer dalam memecahkan masalah semi-terstruktur dengan memberikan informasi ataupun usulan menuju pada keputusan tertentu (Hermawan, 2005).

Pembuatan keputusan merupakan fungsi utama seorang manajer atau administrator. Kegiatan pembuatan keputusan meliputi pengidentifikasian masalah, pencarian alternatif penyelesaian masalah, evaluasi dari alternatif-alternatif tersebut dan pemilihan alternatif keputusan yang terbaik. Kemampuan seorang manajer dalam mengambil keputusan dapat ditingkatkan apabila mengetahui dan menguasai teori dan teknik pembuatan keputusan. Dengan peningkatan kemampuan manajer dalam pembuatan keputusan diharapkan dapat ditingkatkan kualitas keputusan yang dibuatnya, dan hal ini tentu meningkatkan efisiensi kerja manajer yang bersangkutan.

Proses pengambilan keputusan terdiri dari empat fase (Kosasi, 2002), yaitu:

1. Penelusuran (Intelligence) : Tahap ini merupakan tahap pendefinisian masalah serta identifikasi informasi yang dibutuhkan yang berkaitan dengan persoalan yang dihadapi serta keputusan yang diambil.

2. Perancangan (Design): Tahap ini merupakan suatu proses untuk mempresentasikan model sistem yang dibangun berdasarkan pada asumsi yang telah ditetapkan. Dalam tahap ini, suatu model dari masalah dibuat, diuji dan divalidasi.

3. Pemilihan (Choice) : Tahap ini merupakan suatu proses melakukan pengujian dan memilih keputusan terbaik berdasarkan kriteria tertentu yang telah ditentukan dan mengarah kepada tujuan yang dicapai.

4. Implementasi (Implementation): Tahap ini merupakan tahap pelaksanaan dari keputusan yang telah diambil. Pada tahap ini perlu disusun serangkaian tindakan yang terencana sehingga hasil keputusan dapat dipantau dan disesuaikan apabila diperlukan perbaikan- perbaikan.

Adapun komponen-komponen dari SPK (Subakti, 2002) adalah:

1. Data Management : Termasuk database, yang mengandung data yang relevan untuk berbagai situasi dan diatur oleh software yang disebut Database Management System (DBMS).

2. Model Management: Melibatkan model finansial, statistikal, management science, atau berbagai model kualitatif lainnya, sehingga dapat memberikan ke sistem suatu kemampuan analitis, dan manajemen software yang dibutuhkan.

3. Communication :User dapat berkomunikasi dan memberikan perintah pada DSS melalui subsistem ini. Ini berarti menyediakan antarmuka. 
4. Knowledge Management : Subsistem optional ini dapat mendukung subsistem lain atau bertindak sebagai komponen yang berdiri sendiri.

\subsection{Metode TOPSIS}

TOPSIS didasarkan pada konsep dimana alternatif terpilih yang terbaik tidak hanya memiliki jarak terpendek dari solusi ideal positif, namun juga memiliki jarak terpanjang dari solusi ideal negatif. Solusi ideal positif didefinisikan sebagai jumlah dari seluruh nilai terbaik yang dapat dicapai untuk atribut/kriteria, sedangakan solusi ideal negatif terdiri dari seluruh nilai terburuk yang dicapai untuk setiap atribut/kriteria. TOPSIS mempertimbangkan keduanya, jarak terhadap solusi ideal positif dan jarak terhadap solusi ideal negatif. Berdasarkan perbandingan terhadap jarak relatifnya, susunan prioritas alternatif bisa dicapai. Metode ini banyak digunakan untuk menyelesaikan masalah pengambilan keputusan secara praktis. Hal ini disebabkan konsepnya sederhana dan mudah dipahami, komputasinya efisien, dan memiliki kemampuan mengukur kinerja relatif dari alternatifalternatif keputusan (Kusumadewi, 2006).

Secara umum, prosedur TOPSIS mengikuti langkahlangkah :

1. Membuat matriks keputusan yang ternormalisasi.

2. Membuat matriks keputusan yang ternormalisasi terbobot.

3. Menentukan matriks solusi ideal positif dan matriks solusi ideal negatif.

4. Menentukan jarak antara nilai setiap alternatif dengan matriks solusi ideal positif dan matriks solusi ideal negatif.

5. Menentukan nilai preferensi untuk setiap alternatif.

TOPSIS membutuhkan rating kerja setiap alternatif $A_{i}$ pada setiap kriteria $C_{j}$ yang ternormalisasi dapat dilihat pada persamaan (1).

$\frac{x_{i j}}{\sqrt{\sum_{i j}^{m} x_{i j}^{2}}}$

dengan $i=1,2, \ldots, m ;$ dan $j=1,2, \ldots, n$; dimana $r_{i j}$ adalah matriks ternormalisasi [i][j] sedangkan $\mathrm{x}_{\mathrm{ij}}$ adalah merupakan matriks keputusan [i][j].

Solusi ideal positif $\mathrm{A}^{+}$dan solusi ideal negatif $\mathrm{A}^{-}$ dapat ditentukan berdasarkan rating bobot ternormalisasi $\left(\mathrm{y}_{\mathrm{ij}}\right)$ dapat dilihat pada persamaan (2).

$\mathrm{y}_{\mathrm{ij}}=$ wi.rij ;

dengan $\mathrm{i}=1,2, \ldots, \mathrm{m} ;$ dan $\mathrm{j}=1,2, \ldots, \mathrm{n}$

$\mathrm{A}^{+}=\left(\mathrm{y}_{1}^{+}, \mathrm{y}_{2}^{+}, \ldots, \mathrm{y}_{\mathrm{n}}^{+}\right)$

$\mathrm{A}^{-}=\left(\mathrm{y}_{1}^{-}, \mathrm{y}_{2}^{-}, \ldots, \mathrm{y}_{\mathrm{n}}^{-}\right)$; dimana $y_{i j}$ adalah matriks ternormalisasi terbobot [i][j] dan $\mathrm{w}_{\mathrm{i}}$ merupakan vektor bobot[i]. Agar dapat menghitung nilai solusi ideal, terlebih dahulu harus menentukan apakah bersifat keuntungan (benefit) atau bersifat biaya (cost). Dimana jika $\mathrm{j}$ adalah atribut keuntungan (benefit) maka $\mathrm{y}_{\mathrm{j}}^{+}$adalah max $\mathrm{y}_{\mathrm{ij}}$ dan $\mathrm{y}_{\mathrm{j}}{ }^{-}$ adalah min $y_{i j}$, sebaliknya jika $j$ adalah atribut biaya (cost) maka $\mathrm{y}_{\mathrm{j}}^{+}$adalah min $\mathrm{y}_{\mathrm{ij}}$ dan $\mathrm{y}_{\mathrm{j}}{ }^{-}$adalah max $\mathrm{y}_{\mathrm{ij}}$.

Jarak antara alternatif $A_{i}$ dengan solusi ideal positif dapat dilihat pada persamaan (3).

$\mathrm{D}_{\mathrm{i}}^{+}=\sqrt{\sum_{i=1}^{n}\left(y_{i}^{+}-y_{i j}\right)^{2}} ; ;=1,2, \ldots, \mathrm{m}$

dimana $\mathrm{D}_{\mathrm{i}}^{+}$adalah jarak alternatif $\mathrm{A}_{\mathrm{i}}$ dengan solusi ideal positif, $\mathrm{y}_{\mathrm{i}}^{+}$merupakan solusi ideal positif[i] dan $\mathrm{y}_{\mathrm{ij}}$ adalah matriks normalisasi terbobot[i][j].

Untuk rumus jarak antara alternatif $\mathrm{A}_{\mathrm{i}}$ dengan solusi ideal negatif dapat dilihat pada persamaan (4).

$\mathrm{D}_{\mathrm{i}}^{-}=\sqrt{\sum_{j=1}^{n}\left(y_{i j}-y_{i}{ }^{-}\right)^{2}} ; \mathrm{i}=1,2, \ldots, \mathrm{m}$

dimana $\mathrm{D}_{i}^{-}$adalah jarak alternatif $\mathrm{A}_{i}$ dengan solusi ideal negatif, $y_{i}^{-}$adalah solusi ideal positif[i] dan $y_{i j}$ merupakan matriks normalisasi terbobot[i][j].

Nilai preferensi untuk setiap alternatif $\left(\mathrm{V}_{\mathrm{i}}\right)$ dapat dilihat pada persamaan (5).

$\mathrm{Vi}=\frac{D_{i}^{-}}{D_{i}^{-}+D_{i}^{+}} \quad ; \quad \mathrm{i}=1,2, \ldots, \mathrm{m}$

dimana $V_{i}$ merupakan kedekatan setiap alternatif terhadap solusi ideal, $\mathrm{D}_{\mathrm{i}}^{+}$adalah jarak alternatif $\mathrm{A}_{\mathrm{i}}$ dengan solusi ideal positif dan $\mathrm{D}_{\mathrm{i}}^{-}$merupakan jarak alternatif $A_{i}$ dengan solusi ideal negatif. Nilai $V_{i}$ yang lebih besar menunjukkan bahwa alternatif $A_{i}$ lebih dipilih.

\section{Metodologi}

\subsection{Tahap Perencanaan}

Pada tahap ini, penulis memahami permasalahan yang muncul pada user mengenai KRS yang kemudian digunakan dalam pembuatan program. Tahap selanjutnya penulis menetukan tujuan pembuatan sistem dan mengidentifikasi kendalakendala yang terjadi pada program terhadap kelayakan pemberian KRS pada nasabah BPD Kaltim. 


\subsection{Tahap Analisis}

Penganalisisan data merupakan tahapan untuk mengidentifikasi sistem dengan penerapan metode yang dipilih sesuai seperti yang diharapkan atau tidak. Serta menganalisis alur fungsi sistem agar sesuai seperti yang diinginkan. Kebutuhan sistem pada penelitian ini mencakup kebutuhan perangkat keras (hardware) dan kebutuhan perangkat lunak (software).

\subsection{Tahap Perancangan (desain)}

Tahap ini menentukan konfigurasi yang dibutuhkan oleh sistem dan metode yang digunakan dalam mengambil keputusan. Seperti pengkoneksian basis data dengan source code sistem pendukung keputusan dan membuat desain antarmuka sistem. Mendesain atau merancang perangkat lunak termasuk didalamnya adalah proses, aturan yang digunakan, UML untuk merancang model sebuah sistem, user interface dan susunan menu dalam aplikasi.

\subsection{Tahap Penerapan (Implementasi)}

Tahap ini merupakan kegiatan untuk mengimplementasikan perancangan sistem yang dibuat seperti desain program aplikasi sistem pendukung keputusan pemberian KRS pada nasabah BPD Kaltim dengan metode TOPSIS. Program yang dibuat diimplementasikan dengan bahasa pemrograman PHP dan basis data yang digunakan adalah MySQL.

\subsection{Tahapan Pengujian (Evaluasi)}

Tahap ini merupakan pengujian sistem oleh user sebagai pengguna, apakah user mengerti atau memahami menu-menu yang tersedia didalam aplikasi baik fungsi dan kegunaannya. Proses uji coba ini untuk mengetahui apakah sistem yang telah dibuat sudah benar dan sesuai dengan karakteristik yang telah ditetapkan, serta mengatasi dan memperbaiki kesalahan-kesalahan yang mungkin terjadi.

\section{Hasil dan Pembahasan}

Dalam sistem ini terdapat beberapa kriteria yang digunakan, yaitu:

1. Karakter, dengan kode kriteria $\mathrm{c} 1$

2. Kemampuan Membayar, dengan kode kriteria c2

3. Jaminan, dengan kode kriteria c3

4. Status Kredit, dengan kode kriteria c4

5. Kondisi Usaha, dengan kode kriteria c5

Metode TOPSIS digunakan untuk menyelesaikan masalah pengambilan keputusan secara praktis. Hal ini disebabkan konsepnya sederhana dan mudah dipahami, komputasinya efisien, dan dapat menghitung nilai bobot dari masing-masing nasabah. TOPSIS mempertimbangkan keduanya, nilai bobot terhadap solusi ideal positif dan nilai bobot terhadap solusi ideal negatif. Berdasarkan perbandingan terhadap nilai bobot, susunan prioritas nasabah penerima KRS bisa dicapai. Alur proses sistem ditunjukkan pada Gambar 1.

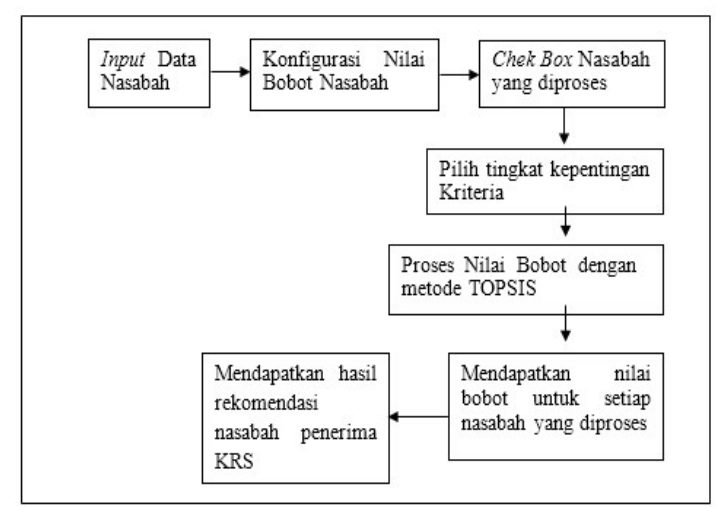

Gambar 1. Alur proses sistem

Pada gambar 1 menjelaskan alur proses sistem dimana admin melakukan input data nasabah KRS yang tersedia seperti bulan pengajuan kredit, nama, alamat, tempat lahir, tanggal lahir, status, pendidikan, nama ibu kandung, status rumah, email, warga negara, nomor KTP, dan nomor NPWP. Setelah admin menekan button "simpan", maka sistem memproses data yang sudah di masukkan oleh admin sebelumnya dan input-an data nasabah dapat dilihat pada tabel nasabah. Selanjutnya admin melakukan konfigurasi nilai bobot nasabah untuk setiap kriteria. Setelah admin menekan button "simpan" maka sistem memproses data input-an yang sudah dimasukan oleh admin dan input-an nilai bobot dapat dilihat pada tabel bobot, kemudian admin melakukan konfigurasi tingkat kepentingan terhadap setiap kriteria, dari proses wawancara oleh analis kredit, tingkat kepentingan dinilai yaitu sangat tidak penting bernilai 1 (satu), tidak penting bernilai 2 (dua), cukup penting bernilai 3 (tiga), penting bernilai 4 (empat), dan sangat penting bernilai 5 (lima). Sebelum lanjut pada proses perhitungan admin checkbox pilih nasabah yang diproses untuk dilanjutkan keperhitungan metode TOPSIS untuk di cari nilai bobot ideal positif dan negatif untuk mendapatkan nilai preferensi calon nasabah penerima KRS yang direkomendasikan. Output sistem berupa hasil rekomendasi dalam bentuk tabel dengan field peringkat, field nama dan field nilai bobot nasabah penerima KRS yang tertinggi sampai terendah.

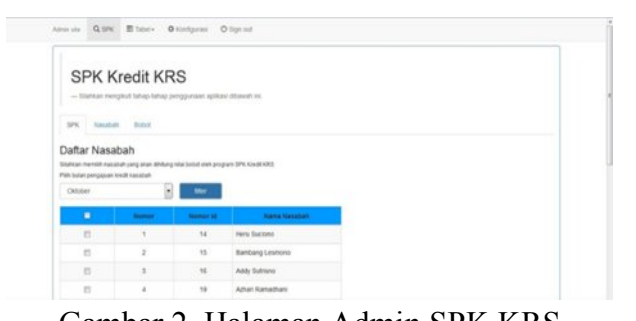

Gambar 2. Halaman Admin SPK KRS 


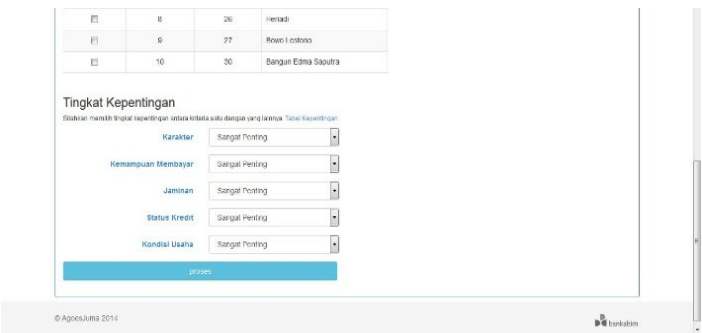

Gambar 3. Halaman Admin SPK KRS

Pada Gambar 2 dan 3 merupakan halaman admin SPK KRS terdapat select option untuk bulan pengajuan kredit, button "filter" untuk mensortir nasabah yang diproses menurut bulan pengajuan kredit, pada halaman admin SPK KRS terdapat tabel dengan field checkbox, field nomor, field nomor id, dan field nama nasabah. Untuk memproses data nasabah dan nilai bobot nasabah yang terdapat pada halaman admin SPK KRS dengan memilih checkbox nasabah yang ingin diproses, sebelumnya admin harus melakukan input data nasabah, konfigurasi nilai bobot nasabah dan tingkat kepentingan kriteria.

Pada Gambar 4 merupakan halaman hasil rekomendasi yang diproses sistem setelah admin memasukan input data nasabah dan memilih check box sesuai pengajuan bulan kredit pada tabel nasabah dihalaman admin SPK KRS, mengkonfigurasi nilai bobot nasabah terhadap kriteria, dan memilih tingkat kepentingan kriteria pada halaman admin SPK KRS selanjutnya sistem memproses data dan nilai bobot dengan metode TOPSIS, yang menghasilkan nilai bobot solusi ideal positif dan negatif dan hasil preferensi nilai bobot nasabah rekomendasi penerima KRS didalam tabel dengan field peringkat, field nama nasabah, dan field nilai bobot nasabah yang tertinggi sampai terendah.

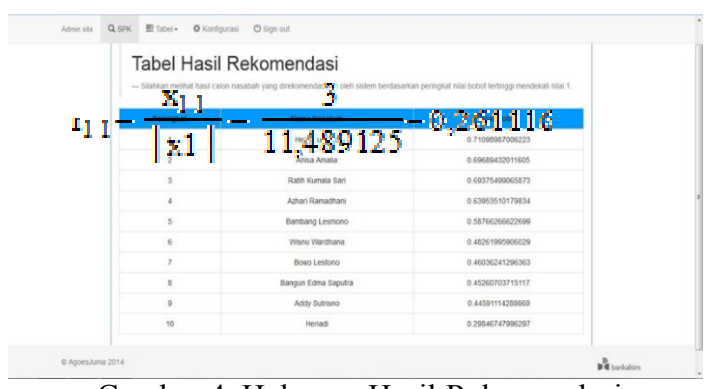

Gambar 4. Halaman Hasil Rekomendasi

Tabel 1. Tingkat kepentingan kriteria

\begin{tabular}{cc}
\hline Nilai & Keterangan Nilai \\
\hline 1 & Sangat Tidak Penting \\
2 & Tidak Penting \\
3 & Cukup Penting \\
4 & Penting \\
5 & Sangat Penting \\
\hline
\end{tabular}

Tabel 1 merupakan tabel nilai kepentingan terhadap setiap kriteria yang dinilai dari 1 (satu) sampai 5 (lima) dari ketentuan analis kredit Bank.

Perhitungan metode TOPSIS nasabah BPD Kaltim dengan cara manual, pertama kita harus mencari nilai bobot nasabah terhadap setiap kriteria, pada sistem pendukung keputusan pemberian KRS pada nasabah BPD Kaltim, nilai bobot ditentukan oleh analis kredit dengan melihat 5 (lima) kriteria, data pribadi, data penghasilan, data jaminan, besarnya pinjaman, uang muka dan masa kredit nasabah serta tujuan pinjaman KRS yang dijadikan acuan dalam pengambil keputusan untuk mencari nilai bobot dan dihitung dengan metode TOPSIS, lihat Tabel 2.

Tabel. 2 Nilai bobot nasabah untuk setiap kriteria

\begin{tabular}{cllllll}
\hline No. & Nama Nasabah & c1 & c2 & c3 & c4 & c5 \\
\hline 1 & Heru S & 3 & 5 & 5 & 2 & 3 \\
2 & Bambang L & 4 & 5 & 5 & 1 & 1 \\
3 & Addy S & 3 & 4 & 3 & 1 & 1 \\
4 & Heriadi & 3 & 4 & 4 & 2 & 1 \\
5 & Bowo L & 4 & 5 & 4 & 3 & 2 \\
6 & Azhari R & 4 & 5 & 5 & 2 & 2 \\
7 & Bangun E. S & 4 & 4 & 5 & 2 & 1 \\
8 & Ratih K.S & 4 & 4 & 5 & 1 & 2 \\
9 & Wisnu W & 3 & 5 & 5 & 2 & 1 \\
10 & Anisa A & 4 & 4 & 5 & 2 & 3 \\
\hline
\end{tabular}

Adapun langkah-langkah algoritma dari perhitungan dengan metode TOPSIS ini adalah:

1. TOPSIS membutuhkan rating kerja setiap alternatif $A_{i}$ pada setiap kriteria $C_{j}$ yang ternormalisasi dapat dilihat pada rumus persamaan (1) adalah.

$$
\begin{aligned}
|x| 1 \mid & =\sqrt{\begin{array}{c}
(3)^{2}+(4)+(3)^{2}+(3)^{2}+(4)^{2}-(4)^{2}+(4) \\
+(4)^{2}+(3)^{2}+(4)^{2}
\end{array}} \\
= & 11.489125
\end{aligned}
$$

Seterusnya sampai $\mathrm{x} 5, \mathrm{r}_{10}$ dengan menggunakan rumus persamaan (1) karena sample nasabah yang dihitung ada 10 (sepuluh). Menggunakan rumus normalisasi persamaan (1), maka didapatkan hasil perhitungan nilai xij seperti yang terlihat pada Tabel 3.

Tabel. 3 Matriks keputusan ternormalisasi

\begin{tabular}{cccccc}
\hline No. & $\mathrm{c} 1$ & $\mathrm{c} 2$ & $\mathrm{c} 3$ & $\mathrm{c} 4$ & $\mathrm{c} 5$ \\
\hline 1 & 0.261116 & 0.355334 & 0.340206 & 0.333333 & 0.507092 \\
2 & 0.348155 & 0.355334 & 0.340206 & 0.166666 & 0.169030 \\
3 & 0.261116 & 0.284267 & 0.204124 & 0.166666 & 0.169030 \\
4 & 0.261116 & 0.213200 & 0.272165 & 0.333333 & 0.169030 \\
5 & 0.348155 & 0.355334 & 0.272165 & 0.500000 & 0.338061 \\
6 & 0.348155 & 0.355334 & 0.340206 & 0.333333 & 0.338061 \\
7 & 0.348155 & 0.284267 & 0.340206 & 0.333333 & 0.169030 \\
8 & 0.348155 & 0.284267 & 0.340206 & 0.166666 & 0.338061 \\
9 & 0.261116 & 0.355334 & 0.340206 & 0.333333 & 0.169030 \\
10 & 0.348155 & 0.284267 & 0.340206 & 0.333333 & 0.507092 \\
\hline
\end{tabular}


2. Menentukan bobot preferensi, yaitu bobot yang menentukan nilai hasil akhir. Bobot preferensi merupakan nilai yang ditentukan dari tingkat kepentingan oleh analis kredit, yaitu 4, 5, 5, 3, 3 . Penjelasan nilai lihat Tabel 1 , nilai yang ditentukan analis ditotal dan dibagi dengan setiap krtiteria maka menghasilkan nilai bobot preferensi, lihat pada Tabel 4 menunjukkan hasil nilai bobot preferensi.

Tabel. 4. Nilai bobot preferensi

\begin{tabular}{ccc}
\hline Kriteria & $\begin{array}{c}\text { Tingkat } \\
\text { Kepentingan }\end{array}$ & $\begin{array}{c}\text { Nilai Bobot } \\
\text { Preferensi }\end{array}$ \\
\hline Karakter & 4 & 0.2 \\
Kemampuan & 5 & 0.25 \\
Membayar & 5 & 0.25 \\
Jaminan & 3 & 0.15 \\
Status Kredit & 3 & 0.15 \\
Kondisi Usaha & 20 & 1 \\
Total & &
\end{tabular}

Mengalikan matriks keputusan ternormalisasi dengan nilai bobot preferensi yang telah ditentukan. Dapat diambil contoh perhitungan perkalian nilai bobot ternormalisasi $\mathrm{X}_{11}$ dengan nilai bobot preferensi dengan nasabah Heru Suciono, adalah:

Nilai bobot ternormalisasi $X_{11}=0,261116$.

Nilai bobot preferensi terhadap kriteria Karakter dengan nasabah Heru Suciono =0.2.

Sehingga didapatkan hasil: $0,261116 \times 0.2=$ 0,052223 , seterusnya seperti rumus perkalian normalisasi dengan 10 (sepuluh) nasabah untuk setiap kriteria.

Perkalian matriks keputusan ternormalisasi pada Tabel 3 dengan nilai bobot preferensi pada Tabel 4, didapatkan nilai yang dapat dilihat pada Tabel 5 .

Tabel. 5 Matriks keputusan ternormalisasi terbobot

\begin{tabular}{cccccc}
\hline \multirow{2}{*}{ No } & \multirow{2}{*}{1} & $\mathrm{c} 2$ & $\mathrm{c} 3$ & $\mathrm{c} 4$ & $\mathrm{c} 5$ \\
\hline 1 & 0.052223 & 0.088833 & 0.085051 & 0.05 & 0.076063 \\
2 & 0.069631 & 0.088833 & 0.085051 & 0.025 & 0.025354 \\
3 & 0.052223 & 0.071066 & 0.051031 & 0.025 & 0.025354 \\
4 & 0.052223 & 0.053300 & 0.068041 & 0.05 & 0.025354 \\
5 & 0.069631 & 0.088833 & 0.068041 & 0.075 & 0.050709 \\
6 & 0.069631 & 0.088833 & 0.085051 & 0.05 & 0.050709 \\
7 & 0.069631 & 0.071066 & 0.085051 & 0.05 & 0.025354 \\
8 & 0.069631 & 0.071066 & 0.085051 & 0.025 & 0.050709 \\
9 & 0.052223 & 0.088833 & 0.085051 & 0.05 & 0.025354 \\
10 & 0.069631 & 0.071066 & 0.085051 & 0.05 & 0.076063 \\
\hline
\end{tabular}

3. Menentukan solusi ideal positif dan solusi ideal negatif yang ditentukan berdasarkan hasil perkalian dari nilai matriks keputusan ternormalisasi dan bobot preferensi menghasilkan matriks keputusan ternormalisasi terbobot, lihat pada Tabel 5. Berdasarkan rumus solusi ideal positif pada persamaan (2).

Dimana nilai tertinggi yang nantinya akan digunakan untuk perhitungan mencari nilai separation measure, sehingga didapatkan nilai: $\mathrm{y} 1+=\max \{0.052223 ; 0.069631 ; 0.052223$; $0.052223 ; \quad 0.069631 ; 0.069631 ; 0.069631$; $0.069631 ; 0.052223 ; 0.069631\}=0.069631$

$\mathrm{y} 2+=\min \{0.088833 ; 0.088833 ; 0.071066$; $0.053300 ; \quad 0.088833 ; \quad 0.088833 ; \quad 0.071066$; $0.071066 ; 0.088833 ; 0.071066\}=0.088833$

$\mathrm{y} 3+=\max \{0.085051 ; 0.085051 ; 0.051031 ;$ $0.068041 ; \quad 0.068041 ; 0.085051 ; 0.085051$; $0.085051 ; 0.085051 ; 0.085051\}=0.085051$

$\mathrm{y} 4-=\max \{0.05 ; 0.025 ; 0.025 ; 0.05 ; 0.075 ; 0.05$; $0.05 ; 0.025 ; 0.05 ; 0.05\}=0.025$ (karena biaya)

$\mathrm{y} 5+=\max \{0.076063 ; 0.025354 ; 0.025354$; $0.025354 ; \quad 0.050709 ; \quad 0.050709 ; \quad 0.025354$; $0.050709 ; 0.025354 ; 0.076063\}=0.076063$

Berdasarkan rumus solusi ideal negatif pada persamaan (2), sehingga di dapatkan nilai:

$\mathrm{y} 1-=\min \{0.052223 ; 0.069631 ; 0.052223 ;$ $0.052223 ; \quad 0.069631 ; \quad 0.069631 ; 0.069631$; $0.069631 ; 0.052223 ; 0.069631\}=0.052223$

$\mathrm{y} 2-=\min \{0.088833 ; 0.088833 ; 0.071066$; $0.053300 ; \quad 0.088833 ; \quad 0.088833 ; 0.071066$; $0.071066 ; 0.088833 ; 0.071066\}=0.053300$

$\mathrm{y} 3-=\min \{0.085051 ; 0.085051 ; 0.051031 ;$ $0.068041 ; \quad 0.068041 ; 0.085051 ; 0.085051$; $0.085051 ; 0.085051 ; 0.085051\}=0.051031$

$\mathrm{y} 4+=\max \{0.05 ; 0.025 ; 0.025 ; 0.05 ; 0.075$; $0.05 ; 0.05 ; 0.025 ; 0.05 ; 0.05\}=0.075$ (karena biaya)

$\mathrm{y} 5-=\min \{0.076063 ; 0.025354 ; 0.025354 ;$ $0.025354 ; \quad 0.050709 ; \quad 0.050709 ; \quad 0.025354$; $0.050709 ; 0.025354 ; 0.076063\}=0.025354$

Sehingga nilai solusi ideal positif dan solusi ideal negatif yang didapatkan terlihat pada Tabel 6 .

Tabel 6. Solusi ideal positif dan solusi ideal negatif

\begin{tabular}{ccc}
\hline Kriteria & $\begin{array}{c}\text { Solusi Ideal } \\
\text { Positif }\end{array}$ & $\begin{array}{c}\text { Solusi Ideal } \\
\text { Negatif }\end{array}$ \\
\hline Karakter & 0.069631 & 0.052223 \\
$\begin{array}{c}\text { Kemampuan } \\
\text { Membayar }\end{array}$ & 0.088833 & 0.053300 \\
Jaminan & 0.085051 & 0.051031 \\
$\begin{array}{c}\text { Status Kredit } \\
\text { Kondisi } \\
\text { Usaha }\end{array}$ & $0.025($ cost $)$ & $0.075($ cost $)$ \\
\hline
\end{tabular}


4. Setelah mendapatkan nilai solusi ideal positif dan solusi ideal negatif, maka langkah selanjutnya adalah menghitung nilai separation measure, pengukuran jarak nilai dari suatu nasabah ke solusi ideal positif $(\mathrm{Di}+)$ dan solusi ideal negatif (Di-) menggunakan rumus pada persamaan (3) dan persamaan (4).

Untuk contoh nasabah Heru Suciono, perhitungan nilai separation measure dapat dilihat pada perhitungan berikut.

$$
\begin{aligned}
\mathbf{D}_{1}^{*} & =\sqrt{\begin{array}{c}
(0.052223-0.069631)^{2}+(0.088833-0.088833)^{2} \\
+(0.085051-0.085051)^{2}+(0.05-0.025)^{2}+ \\
(0.076063-0.076063)^{2}
\end{array}} \\
& =0.030463
\end{aligned}
$$

$$
D_{l}^{-}=\sqrt{\begin{array}{c}
(0.052223-0.052223)^{2}+(0.088539-0.053900)^{2} \\
+(0.085051-0.051031)^{2}+(0.05-0.075)^{2}+ \\
(0.076063-0.025354)^{2}
\end{array}}
$$

Dan seterusnya $\mathrm{D}_{10}^{-}, \mathrm{D}_{10}$ seperti rumus persamaan (3) dan (4) karena sample 10 (sepuluh) nasabah, maka di dapatkan nilai separation measure untuk semua nasabah seperti yang dapat dilihat pada Tabel 7.

Tabel. 7 Nilai separation measure

\begin{tabular}{lcc}
\hline \multicolumn{1}{c}{ Nama Nasabah } & $\begin{array}{c}\text { Jarak Nilai } \\
\text { Maksimum }\end{array}$ & $\begin{array}{c}\text { Jarak Nilai } \\
\text { Minimum }\end{array}$ \\
\hline Heru Suciono & 0.030463 & 0.074943 \\
Bambang Lesmono & 0.050709 & 0.072270 \\
Addy Sutrisno & 0.065935 & 0.053062 \\
Heriadi & 0.071073 & 0.030238 \\
Bowo Lestono & 0.058585 & 0.049978 \\
Azhari Ramadhani & 0.035606 & 0.063173 \\
Bangun Edma & 0.059262 & 0.049000 \\
Saputra & & \\
Ratih Kumala Sari & 0.030959 & 0.070135 \\
Wisnu Wardhana & 0.059156 & 0.055181 \\
Anisa Amalia & 0.030670 & 0.070516 \\
\hline
\end{tabular}

5. Langkah selanjutnya yaitu menghitung kedekatan relatif dari nasabah yang ada terhadap jarak solusi ideal positif dan negatif. Dengan menggunakan rumus pada persamaan (5).

Kedekatan relatif nasabah Heru Suciono, dengan solusi ideal dapat dilihat pada perhitungan berikut.

$$
V_{1}=\frac{0074943}{0.074943+0.030463}=0.710989
$$

Dan seterusnya sampai $V_{10}$, seperti rumus persamaan (5) karena 10 (sepuluh) nasabah.
Sehingga nilai preferensi untuk nasabah Heru Suciono, yaitu 0.710989. Dengan menggunakan rumus perhitungan separation measure maka didapatkan nilai akhir untuk semua nasabah yang dapat dilihat pada Tabel 8.

Tabel. 8 Hasil akhir

\begin{tabular}{clc}
\hline Peringkat & \multicolumn{1}{c}{ Nama Nasabah } & $\begin{array}{c}\text { Nilai Hasil } \\
\text { Akhir }\end{array}$ \\
\hline 1 & Heru Suciono & 0.710989 \\
5 & Bambang Lesmono & 0.587662 \\
9 & Addy Sutrisno & 0.445911 \\
10 & Heriadi & 0.298467 \\
7 & Bowo Lestono & 0.460362 \\
4 & Azhari Ramadhani & 0.639535 \\
8 & Bangun Edma Saputra & 0.452607 \\
3 & Ratih Kumala Sari & 0.693754 \\
6 & Wisnu Wardhana & 0.482619 \\
2 & Anisa Amalia & 0.696894 \\
\hline
\end{tabular}

Nilai akhir yang mendekati 1 (satu) merupakan nasabah yang mempunyai jarak terdekat dengan solusi ideal positif dan memiliki jarak terjauh dengan solusi ideal negatif.

Dari Tabel 8 dapat dilihat hasil rekomendasi yang diberikan kepada analis kredit. Hasil rekomendasi peringkat pertama dengan nilai bobot mendekati nilai 1 (satu) dengan nilai bobot 0.710989 adalah nasabah Heru Suciono. Selanjutnya peringkat kedua dengan nilai bobot 0.696894 adalah nasabah Anisa Amalia dan peringkat ketiga dengan nilai bobot 0.693754 adalah nasabah Ratih Kumala Sari.

Urutan rekomendasi nasabah KRS yang dihitung dengan cara manual sesuai dengan urutan peringkat rekomendasi nasabah KRS yang ditampilkan oleh sistem seperti yang terlihat pada Tabel 9 pengujian system.

Tabel 9. Pengujian sistem

\begin{tabular}{clc}
\hline Peringkat & \multicolumn{1}{c}{ Nama Nasabah } & Nilai Bobot \\
\hline 1 & Heru Suciono & 0.71098987006223 \\
2 & Anisa Amalia & 0.69689432011605 \\
3 & Ratih Kumala Sari & 0.69375499065873 \\
4 & Azhari Ramadhani & 0.63953510179834 \\
5 & Bambang Lesmono & 0.58766266622699 \\
6 & Wisnu Wardhana & 0.48261995906029 \\
7 & Bowo Lestono & 0.46036241296363 \\
8 & Bangun Edma & 0.45260703715117 \\
9 & Saputra & \\
10 & Addy Sutrisno & 0.44591114289869 \\
& Heriadi & 0.29846747996297 \\
\hline
\end{tabular}

\section{Kesimpulan}

Pemilihan nasabah penerima KRS menggunakan sistem pendukung keputusan yang dibangun mempunyai kinerja yang lebih baik dari pada pemilihan nasabah penerima KRS dengan cara 
pengambilan keputusan yang dilakukan oleh staf penganalisis kredit (account officer), selalu memiliki banyak kendala, seperti proses pengambilan keputusan yang tidak efektif (penggunaan waktu yang cukup lama, tenaga dan biaya yang terbuang), human error dan adanya kemungkinan kolusi antara calon nasabah dan petugas Bank.

Dari hasil pengujian sistem yang telah dilakukan dapat disimpulkan bahwa sistem pendukung keputusan pemberian KRS pada nasabah BPD Kaltim dapat memberikan hasil rekomendasi penerima KRS berdasarkan sistem sesuai dengan nilai bobot input-an yang dimasukkan oleh analis kredit.

\section{Daftar Pustaka}

Hermawan, J., 2005. Membangun Decision Support System, Andi, Yogyakarta.

Kosasi, S., 2002. Sistem Pendukung Keputusan (Decision Support System), Pontianak Cerdas. Terjemahan Dwi Prabantini, Yogyakarta: Andi

Kusumadewi, S., 2006. Fuzzy Multi-Attribute Decision Making (Fuzzy MADM), Graha Ilmu, Yogyakarta.

Nasution, L.F., 2009. Perancangan Sistem Pendukung Keputusan Kredit Kepemilikan Rumah Di Bank Syari'ah Cabang Medan. Skripsi Sarjana, Ilmu Komputer Fakultas MIPA, Universitas Sumatera Utara, Medan.

Subakti, I., 2002. Sistem Pendukung Keputusan (Decision Support System), Teknik Informatika, Fakultas Teknologi Informasi Institut Teknologi Sepuluh November, Surabaya. 